\title{
Påverkar covid-19 lärares betygs- och bedömningspraktik?
}

\author{
Linda Ekström Lind \\ Cornelia Wilhelmsson \\ Anna Martin Bylund \\ Linneá Stenliden
}

\author{
0703608901
}

Studien genomfördes 19 mars - 2 april 2020. Inom ramen för det nationella projektet "Utbildning, lärande och forskning” (ULF) dokumenterade tre högstadielärare och två gymnasielärare, samtliga svensklärare, fördelade på fyra olika skolor, sina upplevelser av skolomställningen med hjälp av dagboks- och reflektionsanteckningar. Detta utgör det empiriska materialet. Lärarna som nämns i artikeln är anonyma och benämns inte vid sina riktiga namn.

\section{En förändrad betygs- och bedömningspraktik}

Den hastiga skolomställningen innebär att lärarna ska genomföra distansundervisning på gymnasiet, hantera parallella praktiker på högstadiet och att i en situation, där elever och lärare helt eller delvis är åtskilda, söka säkerställa rättssäkra betyg. Att sätta betyg innebär att läraren i slutet av terminen/kursen bedömer i vilken mån eleven uppnått kunskapskraven. All tillgänglig information om elevens kunskaper ska beaktas och en allsidig utvärdering i förhållande till kunskapskraven ska? göras (Skolverket, 2018). Bedömningen är då summativ (summerar elevens kunskaper till ett betyg) och holistisk (bygger på lärarens helhetsbild av elevens kunskaper), men vid insamlingen av underlaget ska bedömningen också vara formativ - återkopplande och framåtsyftande för både elever och lärare. Bedömningen kartlägger alltså kunskaper men värderar, synliggör och återkopplar samtidigt, vilket formar elevens lärande och lärarens undervisning. Den summativa bedömningen (betyget) ska grundas på både informella och formella bedömningssituationer. Informell bedömning sker kontinuerligt genom t.ex. samtal/observation under processen medan den formella bedömningen innebär "tydligt uttalade bedömningssituationer oftast avsedda för hela undervisningsgruppen" (Skolverket, 2011, s.10) såsom skriftliga prov eller skrivuppgifter. Bedömningarna ska vara både formativa och summativa, "ändamålsenliga", gynna elevens kunskapsutveckling och säkerställa "ett brett och varierat underlag inför betygsättningen" (Skolverket 2018, s. 17). Insamlingen av ett allsidigt, tillförlitligt betygsunderlag försvåras dock våren 2020 och en förändrad bedömningspraktik skapas som här beskrivs utifrån begreppen validitet och reliabilitet. 
En rättssäker bedömning ska vara så rättvisande och likvärdig som möjligt och vila på "vetenskaplig grund och beprövad erfarenhet" (Skolverket, 2018, s. 5). För att möjliggöra detta ska bedömningssituationer utformas så att validitet och reliabilitet, vilket McMillan (2017) menar kännetecknar högkvalitativa bedömningar, uppnås. Validitet säkerställer att det som avsetts bedömas faktiskt bedöms dvs. elevens kunskap inom ett givet område. Här innefattas att undervisningen, som föregått bedömningen, ska ge eleven rätt förutsättningar inför bedömningen. Likaså ska bedömningssituationen utformas så att det som ska mätas kan visas under rimliga förutsättningar - ex. rimlig tid till förfogande. Reliabilitet handlar om tillförlitlighet och kontinuitet i elevens producerade underlag, att kunskapsutveckling över tid möjliggjorts. Eleven ska få uppvisa sina kunskaper vid flera tillfällen. Vid hög överensstämmelse kan reliabiliteten bedömas som hög, och vice versa (Skolverket, 2017, McMillan, 2017).

Att iscensätta informell och formell bedömning försvåras vid distansläget då formell bedömning inte kan övervakas i samma utsträckning som vanligt. Därmed blir regelbrott och fusk svårare att upptäcka och förhindra (Skolverket, 2020a), vilket förstärks av att de digitala verktygen inte är anpassade för distansbedömning (Bergendahl \& Nouri, 2020). När de nationella proven, som särskilt ska beaktas i betygsättning (Skolverket, 2018) utgår tilltar utmaningen ytterligare. Lärare uppmanas använda befintliga betygsunderlag samt söka alternativa, nya möjligheter till bedömning (Skolverket, 2020a). Allt detta förskjuter villkoren för betygs- och bedömningspraktiken och nya krav ställs på lärarna.

\section{Distansläge påverkar reliabiliteten}

Reliabiliteten försämras alltså då lärare i distansläget inte kan säkerställa upphovsmannen, eller med säkerhet veta om otillåtna metoder använts. Uteblivandet av de vanliga kontrollfunktionerna skapar problem för högstadieläraren Kim, när elever som vistas hemma på grund av symtom, examineras:

"På skolan där jag jobbar har vi för närvarande ingen granskning av elevers texter. Program och tjänster som Urkund lyser med sin frånvaro och det enda vi har att jobba med är "det sunda förnuftet". Det sunda förnuftet innebär att vi, emot all forskning som finns kring betygssättning och lärande, ska reagera om en elev som annars är svag skriver något som är av hög kvalité. Det känns fel att misstänkliggöra en elev för fusk på grund av att eleven inte brukar prestera högt. Vem är jag att misstänkliggöra en elev som eventuellt presterar bättre i en hemmiljö, i lugn och ro i sitt eget rum, utan störningsmoment från dennes klasskamrater?"

Begränsad möjlighet att säkerställa att elevens prestation motsvarar de reella kunskaperna skapar frustration. Kim kan inte säkert veta vem som skrivit texten eller om otillåten hjälp tagits från exempelvis internet, kompisar eller föräldrar. Enbart misstanke om att bedömningen kan vila på felaktiga grunder minskar reliabiliteten. Om eleven fuskat påverkas även validiteten då Kim inte kan veta om det som avsetts bedömas verkligen har bedömts. Att prestationen kan gynnas av att eleven skrivit hemma där det eventuellt är lugnare och enklare att koncentrera sig än i klassrummet, är dock också möjligt. Förändrade förutsättningar kan ha lett till en bättre prestation än tidigare och därför vill Kim inte misstänkliggöra eleven och riskera att förstöra den goda relationen dem emellan. Kim aktiverar här en respons- och ansvarskapabel pedagogik och använder sin moraliska kompass för att hantera en ny, ovan praktik som skapar nya dilemman (Ekström Lind et al, 2020). I den förändrade bedömningssituationen saknas tydliga upptrampade stigar gällande rätt och fel, och i detta fall görs en riskbedömning där tilliten mellan lärare och elev samt elevens trovärdighet, vägs mot reliabiliteten. Detta är inte oproblematiskt:

"Jag känner en stor oro inför detta, eftersom ingen tjänst eller program garanterar upphovsmannen. Det skulle i teorin kunna vara ett äldre syskon eller kompis som har producerat texten och i en vanlig klassrumsmiljö har man en större möjlighet att följa eleven och dess textproduktion och på så sätt garantera vem som har skrivit majoriteten av texten." 
Om rättssäkerheten, och därmed lärarens trovärdighet i betygsättningen ska värnas, riskeras istället den tillitsfulla relationen. Likaså begränsas den informella bedömningssituationen. I klassrummet kan skrivprocessen följas och reliabiliteten säkerställas och Kim kan arbeta formativt: handleda, se att eleven fokuserar på rätt saker och förstår uppgiften, vilket stärker validiteten. Vid distansundervisning har elever visat sig arbeta mer självständigt och individuella behov upptäcks inte lika lätt, dessutom uteblir oftare individuell handledning (Kavadze \& Basilaia, 2020, Zhou et al, 2020). Mot en sådan bakgrund kan elever på distans prestera både bättre (som i exemplet) och sämre än normalt.

\section{De förlorade nationella proven}

Den 23 mars förskjuts bedömningspraktiken ytterligare när de nationella proven ställs in. Administrationen bedöms olämplig när lärarnas arbetsbelastning redan är hög och proven inte anses "uppfylla sitt betygstödjande syfte" (Skolverket, 2020b). Detta försvårar för gymnasieläraren Mika:

"Som ämnesansvarig i svenska har jag tillsammans med mina kollegor nu i åtta år arbetat upp ett gediget material och tillvägagångssätt för att lägga upp vår undervisning så att den blir jämlik och strukturerad. Och i denna fas har vi börjat planera för nationella prov och vissa av oss har delat ut instruktionerna för de muntliga nationella proven i Svenska 1 men inte alla. Alla blir ställda och undrar hur det nu blir med de nationella proven. [...] Under några dagar lusläser jag alla nyheter och lyssnar på uttalanden på radion och inser att vi troligen kan räkna med att de nationella proven ställs in. Under tiden arbetar jag då med att digitalisera det gamla nationella prov som vi har tillgång till på skolan och som inte är under sekretess. Vi kommer troligen att kunna lösa vår situation genom att ge elever uppgifter och texter digitalt och känner oss mindre oroade. Dagen efter kommer också beskedet om att provet ställs in. Jag meddelar mina lärare att vi kan arbeta med det gamla provet."

De förändringar som Skolverkets beslut skapar leder till oro. Undervisningsstrukturen, som leder fram till de nationella proven, syftar till att skapa validitet och reliabilitet. Proven är noga utprovade och genomförs under kontrollerade former av alla, som har svenska 1 som avslutande kurs, i hela landet. Detta möjliggör sambedömning, vilket Skolverket framhåller som viktigt för att det kan skapa samsyn kring "vad som ska bedömas och hur bedömningen ska gå till" (Skolverket, 2018, s. 22) både på lokal och nationell nivå. Ökad samsyn kring bedömning underlättas av de vägledande bedömningsanvisningar som medföljer proven, och kan också precis som på Mikas skola leda till samsyn även kring undervisning. Detta stärker därmed både reliabiliteten och validiteten. Att proven delvis kan användas summativt och att de särskilt ska beaktas i betygsättningen (Skolverket, 2018) ökar också dess betydelse. De blir som kvitton på huruvida eleven tillskansat sig innehållet i undervisningen eller ej.

För att hantera problemet, när proven ställs in söker Mika och kollegor digitalisera gamla icke sekretessbelagda prov. Mika kontaktar Skolverket gällande detta, men myndigheten menar att:

"[...] inget nationellt prov får läggas ut digitalt där texter ingår eftersom det kan vara ett brott mot upphovsrätten.[...] Genast måste jag kontakta mina kollegor och dra tillbaka allt om att de kan använda det gamla nationella provet. I stället får jag sätta mig med häftet och söka efter texterna som tillhör det nationella provet och se om artiklarna finns öppna på nätet. Jag hittar alla utom en och lyckas på fyra timmar skapa ett alternativt liknande nationellt prov och läsförståelseprov till mig och mina kollegor. [...] Två veckor senare har Skolverket inte kommit med någon särskild hjälp i frågan utan meddelar att lärare har annat material under året att tillgå vid betygsättning."

Helt inställda prov verkar för Mika inte vara ett alternativ, trots att distansläget äventyrar reliabiliteten; en lika tillförlitlig bedömningssituation som vanligt kan inte åstadkommas i distansläget och proven fyller därmed inte sitt betygsstödjande syfte, vilket också Skolverket påpekar (2020b). Den nya skolpraktiken utmanar lärarna och de invanda formerna och 
upprätthållande strukturerna uteblir. Det skapar frustration men även kreativitet och ifrågasättande, vilket också på sikt kan skapa utveckling.

\section{Implikationer}

En förändrad skolpraktik medför en förändrad betygs- och bedömningspraktik och när informell och formell bedömning försvåras påverkas validiteten och reliabiliteten, vilket riskerar rättssäkerheten. Ett tungt ansvar vilar på lärarna som liksom omgivningen värnar rättssäkra betyg vilka ska kunna utgöra det urvalsinstrument de är tänkta att vara. Reliabiliteten kan dock inte garanteras i distansläget och validiteten är osäker då elevernas kunskapsutveckling kan försämras av brist på närundervisning. Upprätthållandet av befintliga strukturer som syftar till validitet försvåras vilket kan skapa kunskapsbortfall och medföra sämre betyg. Lärare kan också tvärtom söka "kompensera" elevernas brist på närundervisning, med eventuellt medföljande kunskapsglapp, genom att inte prioritera reliabiliteten i lika hög utsträckning och därmed basera betyg på mindre tillförlitliga underlag än vanligt. Det skulle kunna generera högre betyg, men om det sker motsvarar inte betygen elevernas kunskaper, vilket hotar rättssäkerheten och det kan i förlängningen leda till ett ifrågasättande av lärarnas professionalitet, vilket också kan drabba eleverna. Kan en "coronageneration", vars reella kunskaper ifrågasätts, skapas om betygen utfärdade under pandemin visar sig vila på vaga grunder? Och om ett faktiskt kunskapstapp konstateras eller om betygen visar sig bli lägre: ska samhället kompensera för det? Sveriges elevkårer menar att arbetslösheten, som följer i pandemins spår, höjer antagningspoängen till universitet- och högskolor vilket gör pandemins gymnasister extra konkurrensutsatta. De efterfrågar därför kompenserande åtgärder från regeringen (Kock \& Rönnqvist, 2021).

Betygsstatistiken för 2020 visar dock att betygen för årskurs 9 ökat med 1,3 procentenheter jämfört med året innan (Skolverket, 2020a), att den genomsnittliga betygspoängen för gymnasisterna i stort sett är oförändrad och att fler tog gymnasieexamen, vilket enligt Skolverket (2020c) beror på faktorer som inte rör pandemin. Betygen är alltså opåverkade, även om siffrorna inte förtäljer om kunskaperna motsvarar betygen. Att betyg, som inte skiljer sig nämnvärt från tidigare år, har kunnat sättas, kan bero på att lärarna haft befintligt betygsunderlag att tillgå eller att de hittat alternativa bedömningssätt som fungerat i distansläget. Det kan dock inte uteslutas att reliabiliteten kan ha bortprioriterats.

I en förändrad vardag där mycket är annorlunda och ovissheten stor försöker lärarna hålla fast i befintliga strukturer och i brist på annat förlita sig på sitt sunda förnuft. Att inga större skillnader i betygsättningen kan påvisas sommaren 2020 är en lättnad, även om konsekvenserna på lång sikt är osäkra. Precis som den nya skolpraktiken kräver responsivitet, anpassningsförmåga och tillit, vilket på sikt kan utveckla nya lärarkompetenser kopplat till digitaliseringen - en reflexiv kvalitativ digital kompetens (Stenliden et al), kanske även en ny betygs-och bedömningspraktik kan utvecklas. Det får framtiden utvisa.

\section{Referenser}

1. Bergdahl, N., \& Nouri, J. (2020). Covid-19 och omställning till distansundervisning i svensk skola. Återföringsrapport 2020-03-27. Stockholms universitet: Stockholm.

2. Ekström Lind, L., Martín Bylund, A., \& Stenliden, L. (2020). Covid-19 i svenska skolor synliggör sårbarhetens potential i lärares praktik. Athena didaktik. Hämtad 13 februari 2021 från: https://atenadidaktik.se/article/view/3345

3. Kvavadze, A., \& Basilaia, G. (2020). Transition to Online Education in Schools during SARSCoV-2 Coronavirus (COVID-19) Pandemic in Georgia. Modestum.

4. Kock, E., \& Rönnqvist, E. (2021). Sveriges Elevkårer och Saco Studentråd. Sveriges Elevkårer och Saco studentråds krav på åtgärder för att säkra ungas framtidsutsikter trots coronapandemin. Hämtad 30 januari 2021 från: https://www.saco.se/saco-studentrad/aktuell t-fran-saco-studentrad/pressmeddelanden/sveriges-elevkarer-och-saco-studentrads-krav-pa- 
atgarder-for-att-sakra-ungas-framtidsutsikter-trots-coronapandemin/

5. McMillan, H, J. (2017). Classroom assessment: Principles and Practice for Effective Standards-Based Instruction, Fifth Edition.

6. Stenliden, L., Martín Bylund, A., Landkvist L., Ekström Lind, L., Kellgren Lundberg, S., Stenmark, H., \& Wilhelmsson, C. (2021). Lärares digitala kompetens före, under och efter covid-19. Utbildning och lärande.

7. Skolverket (2011). Kunskapsbedömning i skolan - praxis, begrepp, problem och möjligheter. Hämtad 25 januari 2021 från: https://www.skolverket.se/download/18.6bfaca41169863e6a6 596de/1553963978320/pdf2660.pdfJJaJ

8. Skolverket (2017). Betyg - deras funktion och vad de mäter. Hämtad 22 januari 2021 från: h ttps://www.skolverket.se/download/18.b173ee8160557dd0b82891/1516017582178/Betygderas-funktioner-och-vad-de-mater\%20.pdf

9. Skolverket (2018). Skolverkets allmänna råd med kommentarer. Betyg och betygsättning. Hämtad 16 november 2020 från: https://www.skolverket.se/download/18.6bfaca41169863e6 a65d5c2/1553968119879/pdf4000.pdf

10. Skolverket (2020a). Slutbetyg i grundskolan våren 2020. Hämtad 16 november 2020 från: https://www.skolverket.se/getFile?file $=7301$

11. Skolverket (2020b). Vårens nationella prov ställs in. Hämtad 16 november 2020 från: https:/ /www.skolverket.se/om-oss/press/pressmeddelanden/pressmeddelanden/2020-03-23-varensnationella-prov-stalls-in

12. Skolverket (2020c). Betyg och studieresultat i gymnasieskolan år 2020. Hämtat 2 februari 2021 från: https://www.skolverket.se/getFile?file=7595

13. Utbildningsdepartementet (2020). The Government's work in the area of education in response to the coronavirus. Hämtad 16 november 2020 från: https://www.government.se/ar ticles/2020/03/the-governments-work-in-the-area-of-education-in-response-to-thecoronavirus/

14. Zhou, L., Li, F., Wu, S., \& Zhou, M. (2020). "School's out, but Class's on", the Largest Online Education in the World Today: Taking China's Practical Exploration during the COVID-19 Epidemic Prevention and Control as an Example. ERIC. Hämtad 13 februari 2021 från: https://eric.ed.gov/?id=ED603937 